\title{
iTRAQ-Based Quantitative Proteomic Analysis of Antibacterial Mechanism of Milk-Derived Peptide BCp12 against Escherichia coli
}

\author{
Kun Yang (D), Yanan Shi ${ }^{D}$, Yufang Li ${ }^{D}$, Guangqiang Wei, Qiong Zhao ${ }^{D}$ and Aixiang Huang *(D) \\ College of Food Science and Technology, Yunnan Agricultural University, Kunming 650201, China; \\ kunyang128611@126.com (K.Y.); yananshihaha@126.com (Y.S.); yufangfangli@126.com (Y.L.); \\ guangqiangwei@126.com (G.W.); zhaoqiong713@126.com (Q.Z.) \\ * Correspondence: aixianghuang@126.com; Fax: +86-0871-364-9220
}

Citation: Yang, K.; Shi, Y.; Li, Y.; Wei, G.; Zhao, Q.; Huang, A.

iTRAQ-Based Quantitative Proteomic Analysis of Antibacterial Mechanism of Milk-Derived Peptide BCp12 against Escherichia coli. Foods 2022, 11, 672. https://doi.org/10.3390/ foods11050672

Academic Editor: Vincenzo Cunsolo

Received: 13 February 2022

Accepted: 21 February 2022

Published: 24 February 2022

Publisher's Note: MDPI stays neutral with regard to jurisdictional claims in published maps and institutional affiliations.

Copyright: (C) 2022 by the authors. Licensee MDPI, Basel, Switzerland. This article is an open access article distributed under the terms and conditions of the Creative Commons Attribution (CC BY) license (https:// creativecommons.org/licenses/by/ $4.0 /)$.

\begin{abstract}
BCp12 is a novel casein-derived antibacterial peptide with a broad-spectrum antibacterial effect. However, its action mechanism against E. coli is unknown. In this study, the growth curve showed that $\mathrm{BCp} 12$ had excellent antibacterial activity against E. coli. Red (propidium iodide staining) and green (fluorescein isothiocyanate staining) fluorescence signals were detected at the edges of the E. coli cells treated with BCp12. scanning electron microscopy (SEM) and transmission electron microscopy (TEM) images showed that $E$. coli cells became rough and shrunken, and part of the cell contents leaked to form a cavity. Furthermore, the iTRAQ proteome analysis showed that 193 and 174 proteins were significantly up-regulated and down-regulated, respectively, after BCp12 treatment. Four enzymes involved in fatty acid degradation of E. coli were down-regulated, disrupting the synthesis of cell membranes. Molecular docking and gel retardation assays showed that BCp12 could bind to genes encoding four key enzymes involved in the fatty acid degradation pathway through hydrogen bonding and hydrophobic interactions, thus significantly inhibiting their activities. Overall, the results indicate that BCp12 inhibits the growth of E. coli, causing metabolic disorders, thus destroying the structure of cell membranes.
\end{abstract}

Keywords: antimicrobial peptide BCp12; Escherichia coli; cell membrane damage; proteomic analysis

\section{Introduction}

Escherichia coli is one of the most common pathogens causing foodborne diseases [1]. It can easily contaminate food during processing and circulation, especially meat products [2]. For instance, $18.37 \%, 16.48 \%$, and $46.4 \%$ of E. coli contamination have been detected in meat products [3], takeout meals [4], and cooked meat products [5], respectively, in Yunnan Province, China. Chemical preservatives, such as potassium sorbate and benzoates, are used to prevent the growth of E. coli in foods [6]. However, frequent or excessive use of chemical preservatives can lead to microbial resistance, accumulation of chemical preservative residues, and change in food quality [7]. Therefore, scholars worldwide have mainly explored drugs with strong antibacterial activity against E. coli [8].

Antimicrobial peptides (AMPs), as natural active peptides [9], have been recognized as promising candidates to address the challenges of limited safety of chemical food preservatives and antibiotic resistance of multidrug-resistant bacteria [10]. Particularly, AMPs derived from milk have become a research hotspot due to their low toxicity, structural diversity, and diverse bactericidal mechanisms of action [11]. In recent years, several studies have found that AMPs can specifically bind to the negatively charged bacterial membrane, interfering with the hydrophobicity of cells and the integrity of cell membranes $[12,13]$. For instance, Turk et al. reported that membrane deformation and structural changes in cell membrane lipids lead to bacterial cell death [14]. Moreso, Li et al. reported that the antibacterial actions of $\varepsilon$-PL against $E$. coli occur through morphological damages and cell 
metabolism inhibition [15,16]. Furthermore, some AMPs can affect the synthesis, expression, and metabolism of bacterial macromolecules through non-membrane permeabilization mechanisms [17], including inhibition of peptidoglycan synthesis [18], direct degradation of target intracellular functions, DNA binding [19], and inhibition of protein synthesis [20]. As a result, it is difficult to clarify the complex and diverse bactericidal mechanisms of antimicrobial peptides. From a technical perspective, most methods (electron microscopic imaging, dye leakage, and gel retardation assays) used to describe the killing mechanisms of AMPs cannot detect the actual interacting components or binding sites. Comparative quantitation of proteomes has become a useful approach for analyzing the underlying mechanism of antimicrobial agents by detecting the differential abundance of proteins. As a result, various studies have utilized the iTRAQ-based quantitative proteomic technology due to its high sensitivity $[21,22]$.

Previous research has demonstrated that BCp12 is a hydrophobic cationic AMP with high thermal stability (primary structure, YLGYLEQLLRLK, and molecular weight, 1508.82 Da) [23]. BCp12 also has a broad-spectrum of antimicrobial activities against foodborne bacteria, including E. coli, Listeria monocytogenes, Salmonella typhimurium, and S. aureus. Besides, BCp12 has minimum inhibitory concentration (MIC, $2 \mathrm{mg} / \mathrm{mL}$ ) of AMPs against $E$. coli. Although BCp12 has antimicrobial spectrums, physicochemical properties, haemolytic properties, hydrophobicity, and surface potential [24], its antibacterial mechanism against E. coli is unknown.

In this study, iTRAQ-based quantitative proteomics and ultrastructural observations using scanning electron microscopy (SEM), transmission electron microscopy (TEM) and confocal laser scanning microscopy (CLSM) were used to investigate the antibacterial mechanism of BCp12 against E. coli at the proteome level. Multiple experiments were further employed for validation. Molecular docking and gel retardation assays were used to verify several differentially expressed proteins. This study can provide significant insights into the molecular mechanism of BCp12 against E. coli pathogens, demonstrating its potential applications in food safety.

\section{Materials and Methods}

\subsection{Materials and Chemicals}

The antibacterial peptide BCp12 was a self-developed sinomenine rennet. A single chromatographic peak was obtained based on living bacteria affinity adsorption and RP-HPLC purification after enzymatic hydrolysis of betelnut river buffalo milk. The chromatographic peak contained four peptide segments. The target active peptide BCp12 was determined through activity screening. Its amino acid sequence was YLGYLEQLLRLK, an antibacterial peptide $\alpha$ s1 casein-derived from antimicrobial peptides and synthesized by Guoping Pharmaceutical Co., Ltd. (purity, over 95\%).

Escherichia coli (E. coli) CICC 10003 was obtained from the China Center of Industrial Culture Collection. The bacterial strains were put in glycerol with nutrient broth at $-80{ }^{\circ} \mathrm{C}$ and were sub-cultured twice in lysogeny broth (LB) medium while agitating (120 rpm) at $37^{\circ} \mathrm{C}$ for $24 \mathrm{~h}$ before use. The initial concentration of the cells was adjusted to $10^{6} \mathrm{CFU} / \mathrm{mL}$ via dilution in phosphate-buffered saline (PBS, $20 \mathrm{mM}$, pH 7.4) for subsequent experiments.

\subsection{Growth Curves of E. coli}

About 1/2 MIC BCp12 was added to the cell culture. The effects of BCp12 on growth curves of $E$. coli cells were investigated using the modified method reported by Su [25]. Sterile water and tetracycline solution $(1 \mathrm{mg} / \mathrm{mL})$ were used as negative and positive controls, respectively. The controls were incubated in a shaker at $37^{\circ} \mathrm{C}$ and $120 \mathrm{r} / \mathrm{min}$ for $24 \mathrm{~h}$. Samples were taken every $2 \mathrm{~h}$. A microplate reader was used to measure the OD600 value. The process was repeated thrice at each time point, and the average values were used to draw a growth curve. 


\subsection{Confocal Laser Scanning Microscopy (CLSM) Assay}

The intracellular localization of FITC-labeled peptides was investigated using a CLSM [26]. The overnight-activated E. coli were diluted to $10^{6} \mathrm{CFU} / \mathrm{mL}$, and FITC-BCp12 (final concentration of $1 \mathrm{MIC}$ ) was added and cultured in a $1.5 \mathrm{~mL}$ centrifuge tube at $37^{\circ} \mathrm{C}$ for $12 \mathrm{~h}$. The bacteria were then washed thrice using PBS, and the bacterial precipitates were collected. PI $(50 \mu \mathrm{g} / \mathrm{mL})$ was added and incubated in an icebox for $15 \mathrm{~min}$, then washed thrice using PBS, and the bacterial precipitation was collected. A Leica AOBS confocal and scanning laser microscope was used for visualization at $488 \mathrm{~nm}, 563 \mathrm{~nm}$, and $271 \mathrm{~nm}$. The images were obtained from $500 \mathrm{~nm}$ to $530 \mathrm{~nm}$ (green channel) and from 535 to $615 \mathrm{~nm}$ (red channel) [27].

\subsection{Determination of the Morphologies of E. coli}

E. coli suspensions (about $10^{6} \mathrm{CFU} / \mathrm{mL}$ ) were prepared and separately treated with $0.5 \times$ and $1 \times$ MIC BCp12. All samples were incubated at $37^{\circ} \mathrm{C}$ for $12 \mathrm{~h}$, and the suspensions were centrifuged at $10,000 \mathrm{rpm}, 4^{\circ} \mathrm{C}$ for $5 \mathrm{~min}$. The precipitated cells were washed thrice and resuspended with PBS. The bacterial precipitate was fixed with $2.5 \%$ glutaraldehyde for $6 \mathrm{~h}$. The fixing solution was subsequently removed via centrifugation. The precipitate was again washed thrice with PBS and dehydrated with ethanol standard solutions in a concentration gradient $(30 \%, 50 \%, 70 \%, 90 \%$, and $100 \%)$ for 10 min (with each ethanol solution in order of increasing concentration). The precipitate was then dried at $60{ }^{\circ} \mathrm{C}$ for sputter coating. Cells treated as described above and not exposed to BCp12 were considered as negative controls. A scanning electron microscope (SIGMA 500/VP, Carl Zeiss, Germany) was used for visualization [28].

\subsection{Transmission Electron Microscopy (TEM) Assay}

E. coli was diluted to $10^{6} \mathrm{CFU} / \mathrm{mL}$, then $\mathrm{BCp} 12$ was added into the fresh cell suspension to a final concentration of $0.5 \times$ and $1 \times \mathrm{MIC}$, and incubated at $37^{\circ} \mathrm{C}$ for $12 \mathrm{~h}$. The treated cells were centrifuged at 10,000 rpm for $5 \mathrm{~min}$, transferred into Eppendorf tubes, and washed thrice using PBS. The resulting cell pellets had a thickness of $\leq 2 \mathrm{~mm}$ and were fixed with glutaraldehyde at $4{ }^{\circ} \mathrm{C}$ for $12 \mathrm{~h}$. The fixed pellets were oxidated by adding $200 \mu \mathrm{L}$ of $1 \%$ osmium tetroxide at $4{ }^{\circ} \mathrm{C}$ for $2 \mathrm{~h}$. The bacterial pellets were then washed thrice using PBS and sequentially dehydrated using 30\%,50\%, 70\%, and 90\% acetone for $10 \mathrm{~min}$ each. The samples were then dehydrated thrice using $100 \%$ acetone for $15 \mathrm{~min}$. Finally, the dehydrated pellets were put into the embedding agent for $72 \mathrm{~h}$. The specimen blocks were hand-trimmed using a razor blade and sectioned using an ultra-microtome (Leica EM UC7, Berlin, Germany). The sections were stained with uranyl acetate for $30 \mathrm{~min}$ and incubated in lead citrate for $10 \mathrm{~min}$. Cells treated as described above and not exposed to $\mathrm{BCp} 12$ were used as negative controls. Transmission electron microscopy (JEOL-JEM-1200 EX, Tokyo, Japan) was used for visualization [29].

\subsection{Proteome Analysis of E. coli}

\subsubsection{Total Protein Extraction}

The protein was extracted using the method described by Ma [30]. E. coli $\left(10^{6} \mathrm{CFU} / \mathrm{mL}\right)$ was cultured in LB broth, then treated with $1 \mathrm{MIC}$ BCp12 (the control was sterile water) at $37^{\circ} \mathrm{C}$ for $14 \mathrm{~h}$. The bacterial cell pellets were collected via centrifugation $\left(10,000 \times g\right.$ at $4{ }^{\circ} \mathrm{C}$ for $5 \mathrm{~min}$ ) and ground into a fine powder in liquid nitrogen. The powder was suspended in lysis buffer (1\% sodium deoxycholate (SDS), $8 \mathrm{M}$ urea) with protease inhibitor to inhibit protease activity. The mixture was allowed to settle at $4{ }^{\circ} \mathrm{C}$ for $30 \mathrm{~min}$ while vortexing the sample every $5 \mathrm{~min}$. The sample was treated via ultrasound at $40 \mathrm{kHz}$ and $40 \mathrm{~W}$ for $2 \mathrm{~min}$. The sample was centrifuged at $16,000 \times g, 4{ }^{\circ} \mathrm{C}$ for $30 \mathrm{~min}$. The BCA protein assay kit (Pierce, Thermo, Fort Pierce, FL, USA) was used to determine the concentration of protein supernatant via the bicinchoninic acid (BCA) method following the kit protocol. 


\subsubsection{Protein Digestion and iTRAQ Labeling}

Protein digestion was performed via the standard procedure. The resulting peptide mixture was labeled using the plex iTRAQ 8-plex iTRAQ reagent (Applied Biosystems, 4390812), following the manufacturer's instructions [31]. Briefly, total protein $(100 \mu \mathrm{g})$ from each sample was mixed with $100 \mu \mathrm{L}$ of the lysate. TCEP $(10 \mathrm{mM})$ was added and stored at $37^{\circ} \mathrm{C}$ for $60 \mathrm{~min}$. Iodoacetamide $(40 \mathrm{mM})$ was then added and stored in the dark at room temperature for $40 \mathrm{~min}$.

Six volumes of cold acetone were added to precipitate protein at $-20^{\circ} \mathrm{C}$ for $4 \mathrm{~h}$, then centrifuged at $10,000 \times g, 4{ }^{\circ} \mathrm{C}$ for $20 \mathrm{~min}$. The pellet was then resuspended with $100 \mu \mathrm{L}$ and $50 \mathrm{mM}$ triethylammonium bicarbonate (TEAB) buffer. Trypsin was then added at 1:50 (trypsin-to-protein mass ratio) and incubated at $37^{\circ} \mathrm{C}$ overnight. One unit of iTRAQ reagent was thawed and reconstituted in $50 \mu \mathrm{L}$ acetonitrile, after incubating at room temperature for $2 \mathrm{~h}$. Hydroxylamine was added at room temperature for $15 \mathrm{~min}$. The samples were labeled as A1-113, A2-114, A3-115, B1-116, B2-117, and B3-118. Finally, all samples were pooled, desalted, and vacuum-dried.

\subsubsection{High $\mathrm{pH}$-RPLC Separation}

ACQUITY ultra performance liquid chromatography (Waters, Fort Pierce, FL, USA) with ACQUITY UPLC BEH C18 Column $(1.7 \mu \mathrm{m}, 2.1 \mathrm{~mm} \times 150 \mathrm{~mm}$, Waters, Fort Pierce, FL, USA) was used to fraction the pooled samples to increase proteomic depth. Briefly, peptides were separated using an elution gradient (Phase B: $5 \mathrm{mM}$ ammonium hydroxide solution containing $80 \%$ acetonitrile, $\mathrm{pH} 10$ ) at a flow rate of $200 \mu \mathrm{L} / \mathrm{min}$ for $48 \mathrm{~min}$. Twenty fractions were collected from each sample, then pooled, obtaining ten fractions per sample.

\subsubsection{LC-MS/MS Analysis}

An online nanoflow liquid chromatography-tandem mass spectrometry was used to assess the labeled peptides via the 9RKFSG2_NCS-3500R system (Thermo, Fort Pierce, FL, USA) connected to a Q Exactive Plus quadrupole orbitrap mass spectrometer (Thermo, Fort Pierce, FL, USA) through a nanoelectrospray ion source [32]. Briefly, the C18-reversedphase column (75 $\mu \mathrm{m} \times 25 \mathrm{~cm}$, Thermo, Fort Pierce, FL, USA) was equilibrated with solvent A (A:2\% ACN with $0.1 \%$ formic acid) and solvent B (B: $80 \%$ ACN with $0.1 \%$ formic acid). The peptides were eluted as follows: $0-63 \mathrm{~min}, 5-23 \% \mathrm{~B} ; 63-82 \mathrm{~min}, 23-29 \% \mathrm{~B} ; 82-90 \mathrm{~min}$, $29-38 \%$ B; $90-92 \mathrm{~min}, 38-48 \%$ B; $92-94 \mathrm{~min}, 48-100 \%$ B; $94-120 \mathrm{~min}, 100-0 \%$ B at a flow rate of $300 \mathrm{~nL} / \mathrm{min}$.

The Q Exactive Plus was operated in the data-dependent acquisition mode (DDA) to switch between full-scan MS and MS/MS acquisition automatically. The orbitrap was used to obtain full-scan MS spectra $(m / z$ 350-1500) with a 60,000 resolution. The automatic gain control (AGC) target was 3e6, and the maximum fill time was $20 \mathrm{~ms}$. The top 20 most intense precursor ions were selected as collision cells for fragmentation using higher-energy collision dissociation (HCD). The MS/MS resolution automatic gain control (AGC) target, maximum fill time, and dynamic exclusion were 15000 (at $m / z$ 100), 5e4, $45 \mathrm{~ms}, 45 \mathrm{~ms}$, and 20 s, respectively.

\subsubsection{Protein Identification}

The Proteome Discoverer (Thermo Scientific, Version 2.4) was used to assess the RAW data files in the E. coli database (https:/ /www.ncbi.nlm.nih.gov/genome/167, accessed on 19 May 2021). The MS/MS search criteria were as follows: Mass tolerance of $10 \mathrm{ppm}$ for MS and 0.02 Da for MS/MS tolerance, trypsin was used as the enzyme with two missed cleavages allowed, carbamide methylation of cysteine and the ITRAQ of N-terminus and lysine side chains of peptides were fixed modifications, and methionine oxidation was the dynamic modifications. FDR $\leq 0.01$ was considered a false discovery rate (FDR) of peptide identification. A minimum of one unique peptide identification was used to support protein identification. 


\subsection{Molecular Docking Analysis}

Target proteins (3-ketoacyl-CoA thiolase, acyl-CoA dehydrogenase, S-(hydroxymethyl) glutathione dehydrogenase, acyltransferase) in the fatty acid degradation pathway that was significantly down-regulated were selected as potential target proteins of BCp12 in molecular docking analysis according to KEGG pathway enrichment analysis $(p<0.01)$. The molecular docking software AutoDock Vina 1.1.2 was used to simulate the interaction between BCp12 and target protein [33]. Schrödinger's Maestro molecular modeling package (Schrödinger, LLC, New York, NY, USA) was used to construct and optimize the structure of BCp12 (YLGYLEQLLRLK). The crystal structures of the target protein were downloaded from the Protein Data Bank (PDB) and Alphfold2 database (https: / /alphafold.ebi.ac.uk/, accessed on 15 December 2021). All receptor proteins were optimized with PyMOL 2.5 before docking, including removing water molecules, salt ions, and small molecules. Second, PyMOL plug-in Centerof_mass.Py was used to calculate the protein centroid and define the center of the docking box to ensure the docking box wrapped the protein site. The ADFRsuite 1.0 was used to convert all processed small molecules and receptor proteins into pdbqt files. The detail of the global search was set to 20 during docking, while the other parameters remained at default settings. The docking conformation with the highest score was used as the combined conformation by default. Finally, the software PyMOL 2.5 was used for visual analysis.

\subsection{Gel Mobility Shift Assay}

Gel mobility shift assay was performed as described by Bandyopadhyay [34] with slight modifications. Briefly, E. coli cells were prepared as described earlier. Bacterial genomic DNA (gDNA) was extracted using an appropriate DNA extraction kit (Soleibao Biotechnology Co., Ltd., Beijing, China). An equal volume of BCp12 solution at different concentrations $(0,1$, and $2 \mathrm{mg} / \mathrm{mL})$ was added to $5.0 \mu \mathrm{L}$ of gDNA, then incubated at $37^{\circ} \mathrm{C}$ for $30 \mathrm{~min}$. Electrophoresis was performed on agarose gel (1\% mass fraction). DNA migration was visualized under UV illumination using a gel imaging system (Bio-Rad, Hercules, CA, USA).

\subsection{Statistical Analysis}

All experiments were performed in triplicate. Data are presented as a mean value and standard deviation (mean \pm SD). GraphPad Prism 8.0.1 and Adobe Illustrator CS6 were used to draw graphs.

\section{Results}

\subsection{The Effect of BCp12 on E. coli Growth}

The inhibitory effects of $\mathrm{BCp} 12$ on E. coli are shown in Figure 1A. E. coli cells grew into stationary phases after $14 \mathrm{~h}$, and the OD600 value reached 0.8 . However, $1 / 2 \mathrm{MIC}$ BCp12 partially inhibited E. coli growth, and the OD600 value reached 0.7 after a 24 -h treatment. Moreover, tetracycline significantly inhibited the growth of E. coli $(p \leq 0.001)$. These results indicate that $\mathrm{BCp} 12$ can inhibit the growth of E. coli. The integrity of the cell membrane was measured to determine the underlying inhibition mechanism of the growth of E. coli after BCp12 treatment. 
A

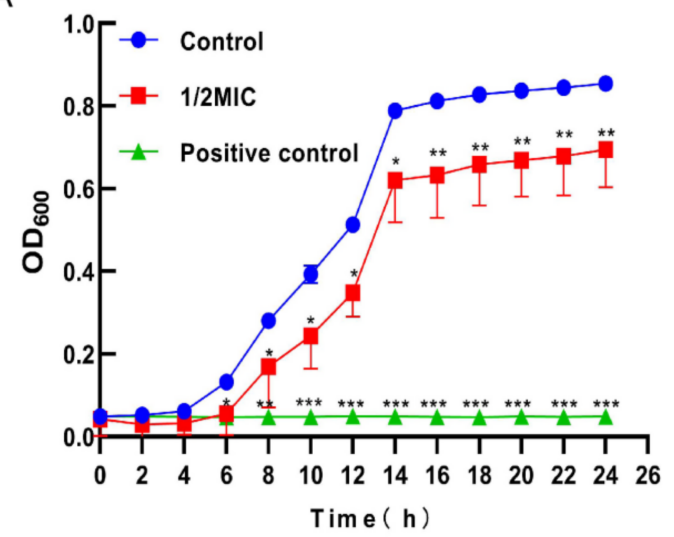

B

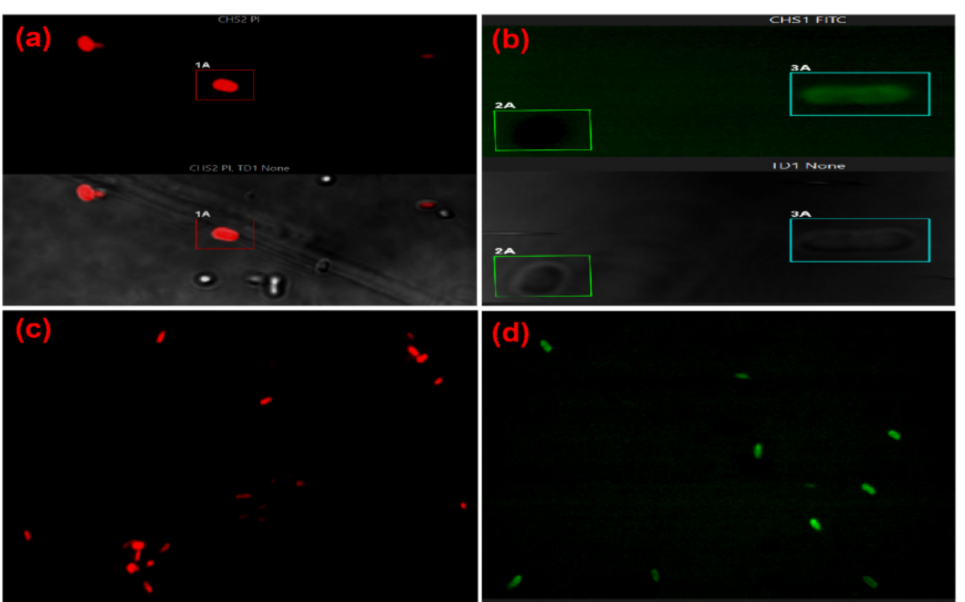

C
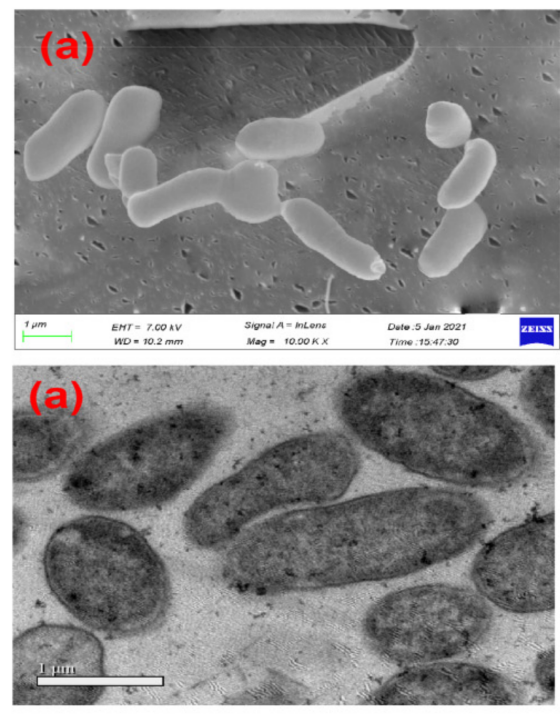
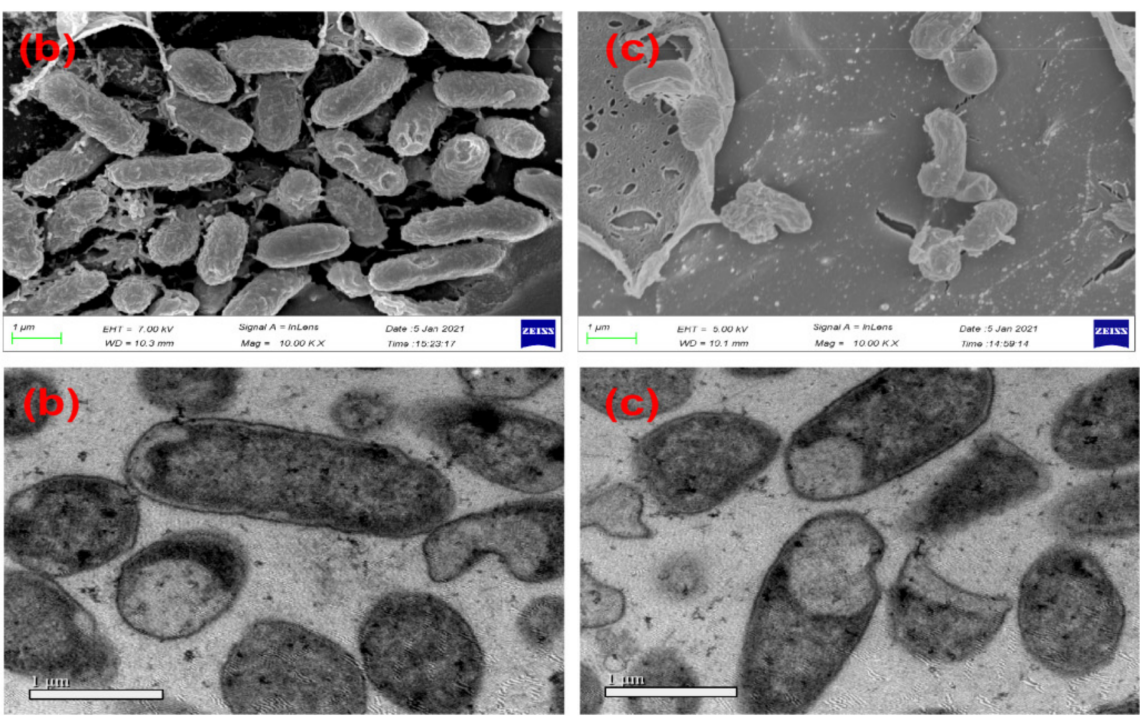

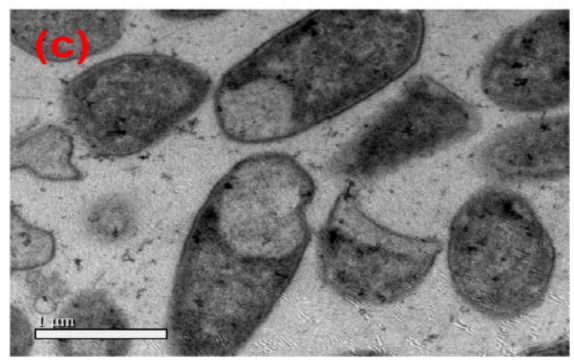

Figure 1. Damage effect of BCp12 to Escherichia coli cell membrane. (A) Growth curves for E. coli cultured in sterile water and 1/2 MIC BCp12. Note: compared with the control group, ${ }^{*}, p \leq 0.05$; ${ }^{* *}, p \leq 0.01 ;{ }^{* * *}, p \leq 0.001$. Each value represents the average of three independent measurements. (B) Effects of BCp12 on cell membrane integrity of E. coli via CLSM. The E. coli cells treated with 1 MIC BCp12 ((a,b) represent the bright field and fluorescence image; $(\mathbf{c}, \mathbf{d})$ represents the image under the fluorescent field). (C) SEM analysis of Escherichia coli under different treatments; (a) - the cells in the untreated E. coli; (b) - the cells after treatment with 1/2 MIC BCp12; (c) - the cells treated with 1 MIC BCp12; (D) TEM analysis of Escherichia coli under different treatments. (a) Untreated $E$. coli. (b) E. coli treated with 1/2 MIC BCp12. (c) E. coli treated with 1 MIC BCp12.

\subsection{Localization Analysis of BCp12 in E. coli Cells}

PI and FITC experiments were conducted to assess if the outer membrane of E. coli was seriously damaged. Red-fluorescent PI is impermeable to the cell membrane and enters cells through compromised membranes, thus staining the nucleic acids [35]. Red (Figure $1(\mathrm{Ba}, \mathrm{Bc})$ ) and green (Figure $1(\mathrm{Bb}, \mathrm{Bd})$ ) fluorescence signals were detected at the edges of the E. coli cells treated with BCp12 (MIC) for $12 \mathrm{~h}$, indicating that the integrity of cell membranes was severely damaged, allowing the entry of FITC-BCp12 and PI (Figure 1B). Benincasa found that antimicrobial peptides first bind to the cell membrane surface of $E$. coli and then enter the cell membrane due to their amphiphilic structure to form short-lived pores [17]. Some peptides are transferred to the lobules in the membrane when these pores are damaged [36], and some cells treated with FITC-F1 conjugate produce yellow-green fluorescence [37]. Furthermore, this study proved that FITC-BCp12 could bind to the cell 
membrane surface of E. coli and then enter the cell membrane because the integrity of the cell membrane of BCp12-treated E. coli was severely damaged.

\subsection{Effect of BCp12 on E. coli Morphologies}

There were significant differences between the control and 1/2 MIC, 1 MIC treatment groups after $12 \mathrm{~h}$ of incubation (Figure 1C). SEM (Figure 1(Ca)) showed that the cells in the untreated E. coli had a smooth, intact, and plump structure. However, E. coli cells showed a plump profile with pustule-like bulges and folds on the surface of the cells after treatment with 1/2 MIC BCp12 (Figure 1(Cb)). The cells treated with 1 MIC BCp12 (Figure 1(Cc)) were significantly deformed and had tears and holes on the surface. The "blanket" model suggests that once the antimicrobial peptide binds to the surface of the bacterial cell membrane, it is covered by a 'carpet', forming an instant hole. The hole subsequently increases the membrane permeability and causes the cell to collapse [38]. Meanwhile, Brogden also found that the blanket model does not require the special structure of AMPs and forms membrane pores; however, the blanket model relies on the positive charge of AMPs to be distributed across the entire polypeptide sequence [39]. The amino acid residue of $\mathrm{BCp} 12$ is YLGYLEQLLRLK conforms to the residue distribution pattern of the antimicrobial peptide in the blanket pattern. Therefore, $\mathrm{BCp} 12$ could have destroyed the cell membrane structure of E. coli through the "blanket mode".

\subsection{The Effect of BCp12 on the Internal Structure of E. coli Cells (TEM Observation)}

As shown in Figure 1(Da), the normal control cells had a fluffy boundary with intact cell wall and membrane structures, and the cell content was substantial and dense. However, the cell membranes had holes, tears, and injuries after BCp12 treatment for $12 \mathrm{~h}$ (Figure 1(Db)) and (Figure 1(Dc)). Besides, there was leakage of intracellular materials, and some cell wall membranes, organelles, and nucleus areas disappeared. Chang demonstrated that OPh-PANF could damage the cell membrane structure of E. coli after $6 \mathrm{~h}$ of treatment, making the cell appear as a vacuole structure [40]. Yang et al. also found that AMPs could rupture the cell membrane, leading to the leakage of intracellular material, thus causing cell death [41,42]. In this study, BCp12 destroyed the cell membrane. Furthermore, $\mathrm{BCp} 12$ could have inhibited the growth of $E$. coli due to the damaged cell membrane.

\subsection{Proteome Analysis}

\subsubsection{Protein Extraction and Basic Identification Information}

SEM and TEM observation showed that BCp12 damaged the cell membranes of E. coli, and iTRAQ proteome analysis was conducted to assess the mechanism of cell membrane damage. The SDS-PAGE results showed that the band distribution and grayscale were the same in the three biologically duplicated protein samples with different treatments (Figure 2A), indicating that the sample was well reproduced from the bacterial culture to protein extraction. Mass spectrometry detected 979,799 spectra in E. coli. The obtained spectra were matched to the protein database of $E$. coli, and 23,469 peptides were identified. Assembly and screening of the peptides were conducted, and 2595 proteins were identified as belonging to the proteome of Escherichia coli (Figure 2B). The relative molecular masses of all the identified proteins were mainly between 1 and $201 \mathrm{kDa}$. A total of 1076 proteins had molecular weights between 21 and $41 \mathrm{kDa}$, with only one protein having 180-201 kDa (Figure 2C). 
A

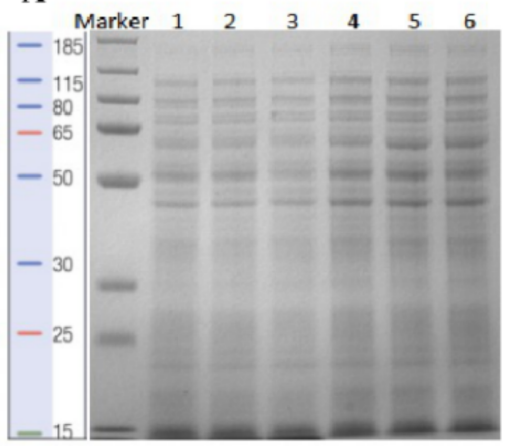

B

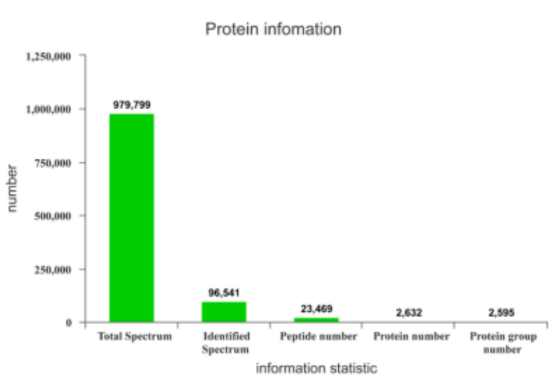

C

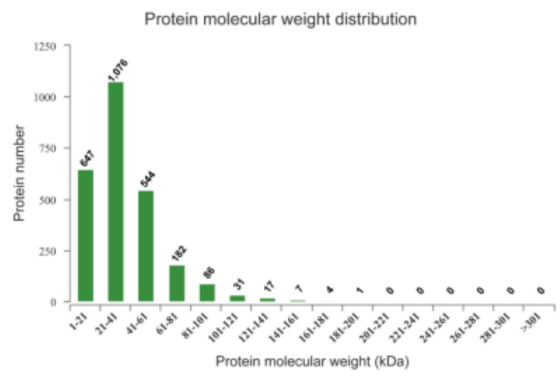

Figure 2. Total protein quantification and basic identification information of E. coli. (A) SDS-PAGE of E. coli proteins; lane 1-3: samples of BCp12 treatment; lane 4-6: samples of $0.1 \mathrm{M}$ PBS buffer treatments (control). (B) Protein information. (C) Protein molecular weight.

\subsubsection{LC-MS/MS Analysis}

The quantitative values with missing data were removed after normalization and then subjected to cluster analysis (Figure 3A). The results showed good reproducibility between the three biological replicates of the $\mathrm{BCp} 12$ treatment group (A1, A2, A3) and the control group (B1, B2, B3). The protein abundance between the control group and the $\mathrm{BCp} 12$-treated group was also significantly different.

The volcano map of the differentially expressed proteins of E. coli was also analyzed (Figure 3B) (X-axis is log2 fold-change). The thresholds of fold-change $(>1.2$ or $<0.83)$ and $\mathrm{p}$-value $<0.05$ were used to identify the differentially expressed proteins. The light blue dots on the upper left indicate significantly down-regulated proteins, and the dark blue dots on the upper right show significantly up-regulated proteins. A total of 193 proteins were significantly up-regulated, and 174 proteins were significantly down-regulated after BCp12 treatment.

\subsubsection{Functional Annotation of Differentially Expressed Proteins}

Differentially expressed proteins of $E$. coli (fold-change $\geq 1.2$ times) were used for Gene Ontology (GO) annotation (http:/ / www.blast2go.com/b2ghome; http:/ / geneontology. org/, accessed on 19 May 2021) (Figure 3). The cellular component analysis (Figure 3C) showed that the protein-containing complex was the most down-regulated. Similarly, the cellular anatomical component of E. coli was the most up-regulated, as shown by pustulelike bulges in SEM (Figure 1C). The molecular functional analysis (Figure 3D) showed that BCp12 treatment had significant binding, catalytic activity, transporter activity, and transcription regulator activity effects. The biological process was annotated using GO Slim to analyze gene functions at a macroscopic level (Figure 3E). BCp12 treatment significantly affected the cellular process, followed by the metabolic process. BCp12 treatment also down-regulated the biological adhesion and multi-organism processes.

\subsubsection{Expression Changes of Cell Membrane-Related Proteins}

Four enzymes involved in fatty acid degradation of E. coli were significantly downregulated after $\mathrm{BCp} 12$ treatment (Figure 4 ) by $<0.83$ folds (fadA; -0.470927 times, fadE; -0.350209 times, frmA; -0.286683 times and aas; -0.337095 times). 
A

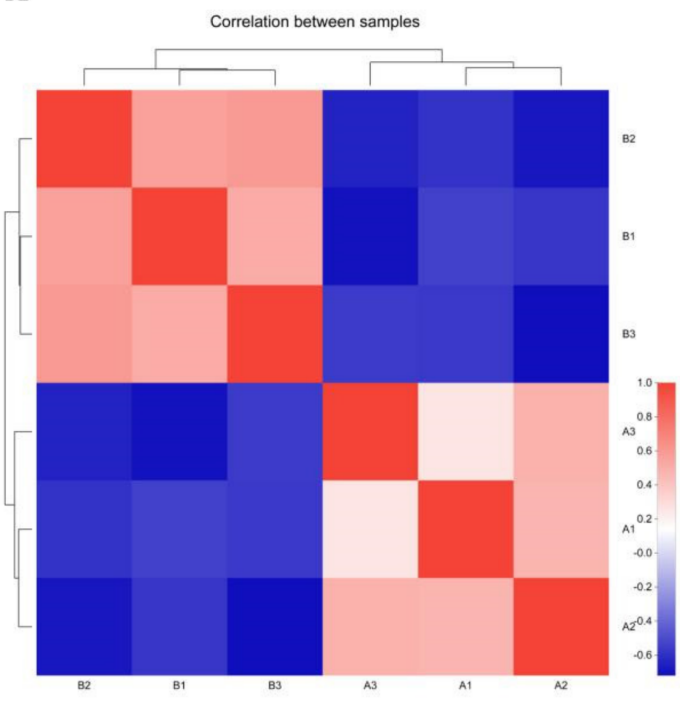

C

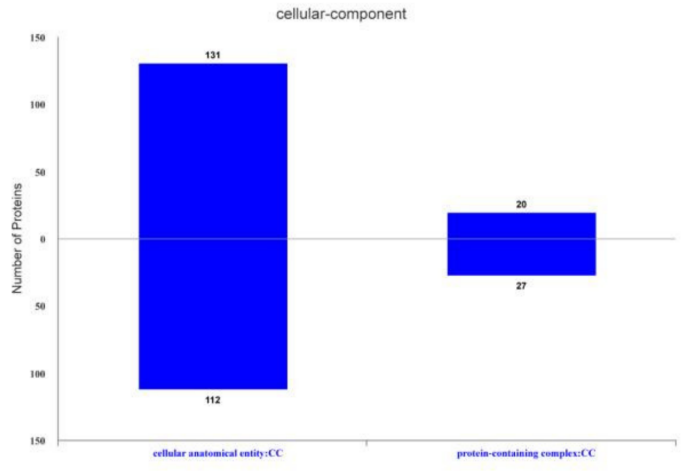

B

A_vs_B.volcano

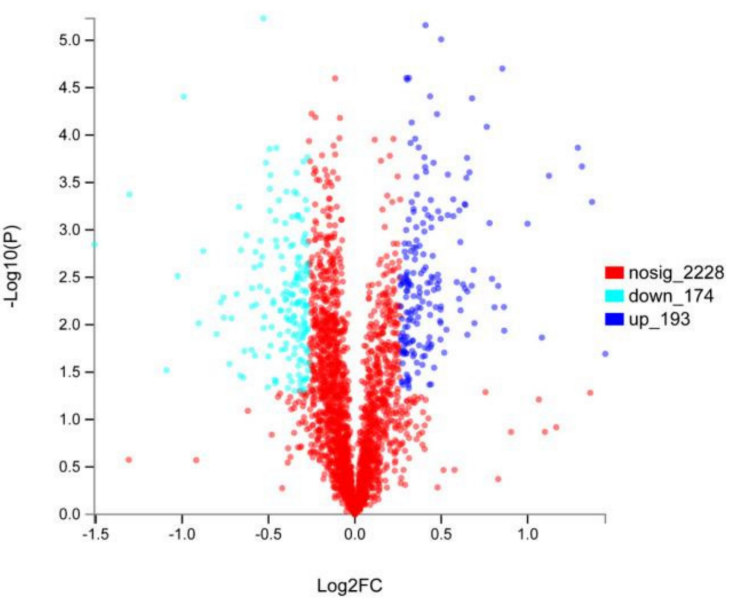

D

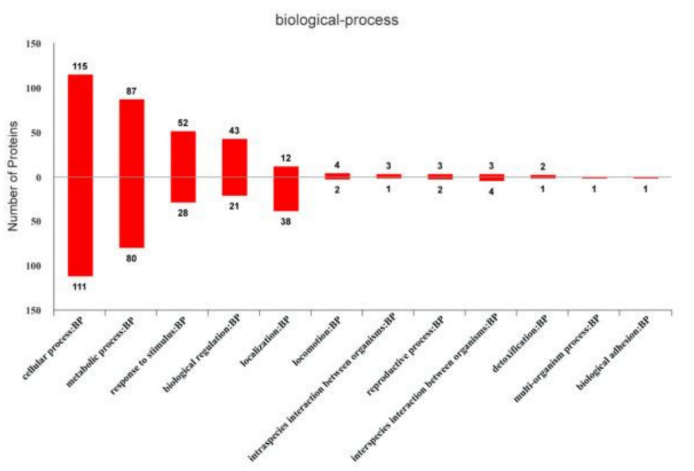

E

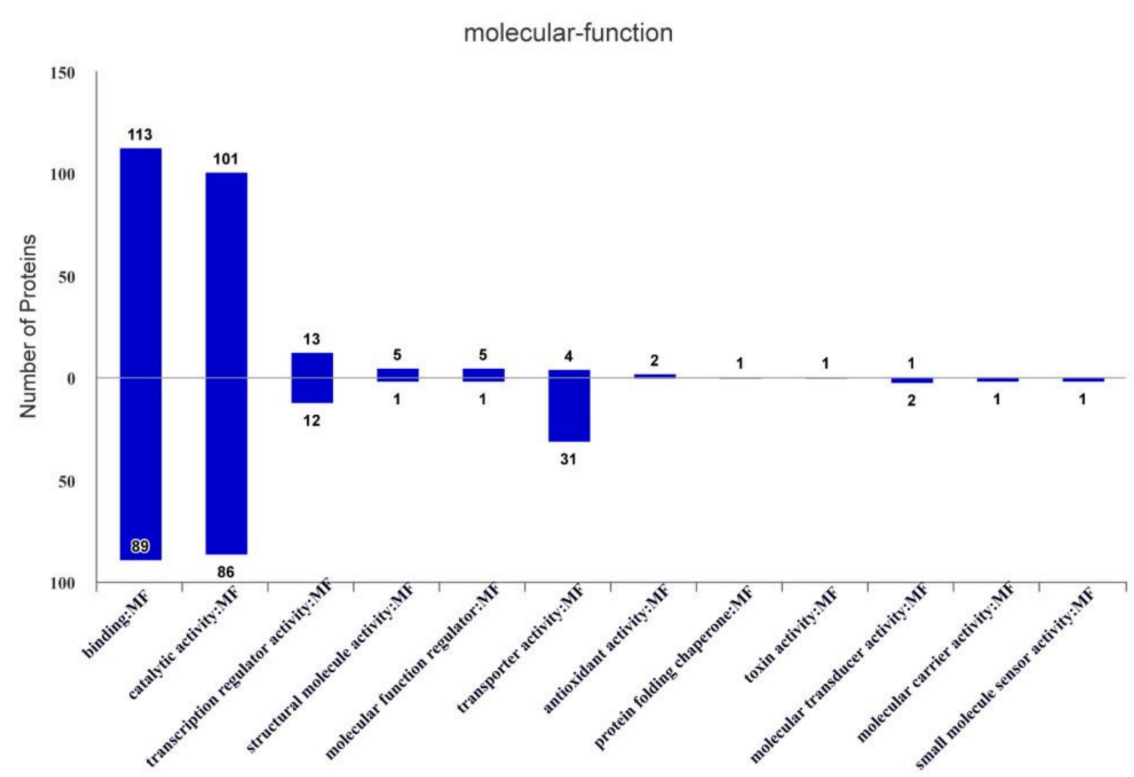

Figure 3. ITRAQ proteome profiling was identified in E. coli treated with BCp12. (A) Heat map of proteins from E. coli; treatments: A1, A2, and A3; control: B1, B2, and B3. (B) The volcano map of the differentially expressed proteins in E. coli. (C) Cellular component of GO analysis. (D) Molecular function of GO analysis (E) Biological process of GO analysis. 


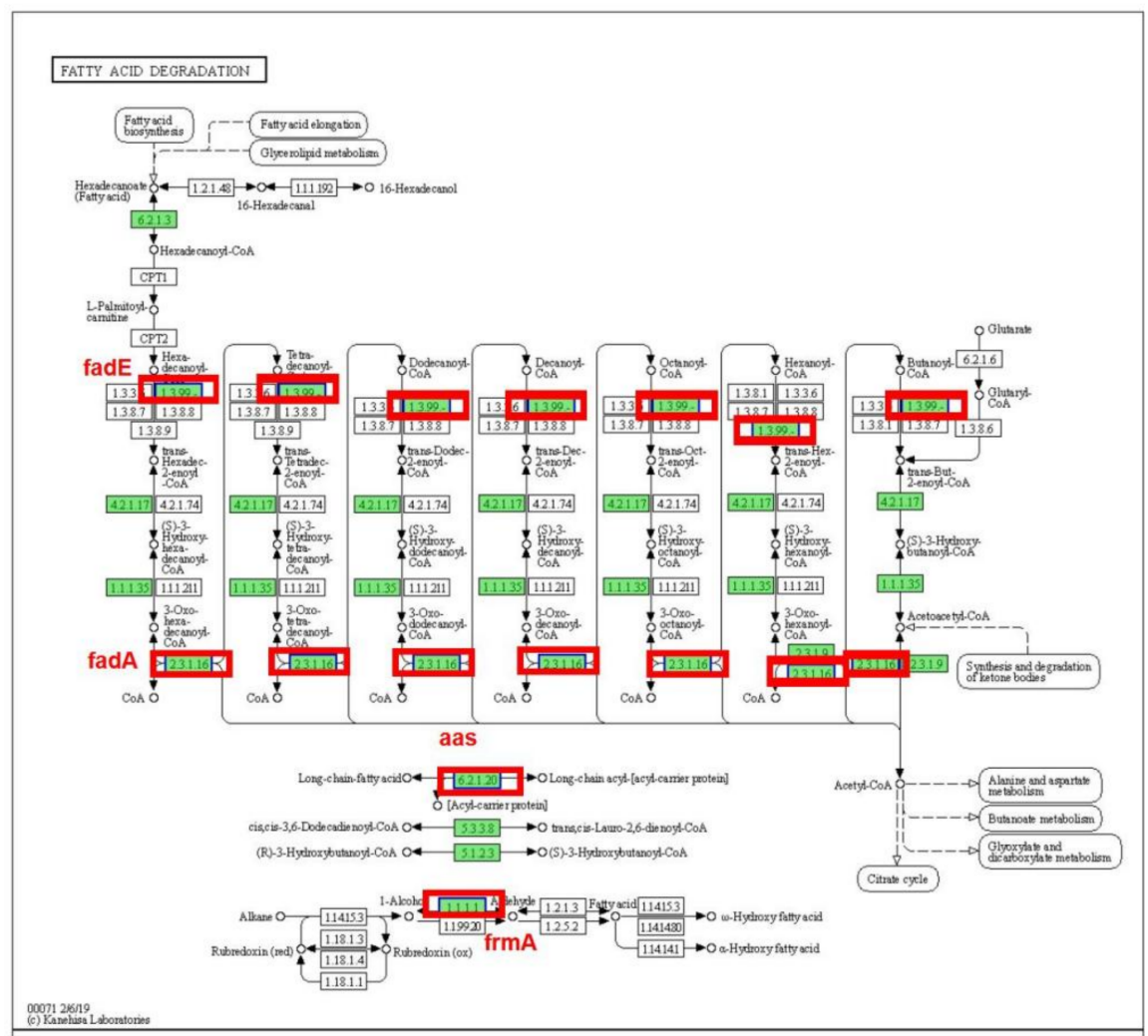

Figure 4. Fatty acid degradation pathway of E. coli; Green indicates down-regulation > 0.83 times; and red shows down-regulation $<0.83$.

Fatty acids are the main components of cell membranes and also precursors of cell envelope biosynthesis [43]. However, $\beta$-oxidation can degrade excess fatty acids or intermediate products of E. coli as follows: fatty acyl-Co A conversion to enoyl-Co A via fade [44]. Besides, fadE is the only acyl-Co A dehydrogenase in E. coli [45]. Knocking out the endogenous fadE gene, which encodes an acyl-CoA synthetase, blocks fatty acid degradation [46]. Some studies have also shown that acetyl-CoA C-acyltransferase fadI and acetyl-CoA C-acyltransferase fadA are significantly down-regulated in BM1157-treated E. coli [47]. Moreso, a loss of frmA increases cell-cell adhesion [48]. Therefore, damage to the E. coli cell membrane may be due to the interaction between $\mathrm{BCp} 12$ and the fadE gene, which decreases fadE enzymatic activity and blocks fatty acid degradation, thereby hindering cell membrane synthesis.

\subsection{Molecular Docking Analysis}

The AlphaFold Protein Structure Database (AlphaFold DB, https: / alphafold.ebi.ac. uk, accessed on 15 December 2021.) is an openly accessible and extensive database that can be used to accurately predict protein structure [49,50]. In this study, the crystal structures of target protein (3-ketoacyl COA thiolase, s-(hydroxymethyl) glutathione dehydrogenase) were downloaded from the Alphfold2 database (https: / / alphafold.ebi.ac.uk/, accessed on 15 December 2021). Molecular docking experiments were then performed to prove the above hypothesis. BCp12 formed hydrogen bonds with residues ala-174 and pro133 and hydrophobic interaction with tyr-178, phe-394, val-67, gln-69, pro-133, pro-41, val-136 and val-171 in the active site of 3-ketoacyl-CoA thiolasecan (Figure 5A). BCp12 also formed hydrogen bonds with residues arg-483, asn-429, gly-428, ser-191, thr-185, Glu-270, pro-220, and arg-416 and hydrophobic interaction with ille-423, pro-419, leu-261, and phe-216 in the active site of acyl-CoA dehydrogenase (Figure 5B). BCp12 formed hydrogen bonds with residues tyr-88, ile-287 and gln-294, and hydrophobic interaction with phe-45, val-291, val-289, ile-296, trp-309, phe-314, leu-105 and ile-287 in the active site 
of acyl S-(hydroxymethyl) glutathione (Figure 5C). Finally, BCp12 formed hydrogen bonds with residue phe-344, arg-10, ser-78, phe-341, pi-pi conjugate with residues phe-146, and hydrophobic interactions with residues met-85, pro-86, VAL-89, Leu-93, leu-97, phe-146, leu-143, pro-340, and phe-341 in the active site of acyltransferase (Figure 5D). Additionally, the best binding energy of $\mathrm{BCp} 12$ to 3-ketoacyl-CoA thiolase, acyl-CoA dehydrogenase, s-(hydroxymethyl) glutathione dehydrogenase and acyltransferase were $-6.3 \mathrm{kcal} / \mathrm{mol}$, $-6.9 \mathrm{kcal} / \mathrm{mol},-7.0 \mathrm{kcal} / \mathrm{mol}$, and $-7.5 \mathrm{kcal} / \mathrm{mol}$, respectively (Table 1 ). The binding energy was less than $-5 \mathrm{kcal} / \mathrm{mol}$, indicating that a stable complex can be formed between ligand and receptor [51].
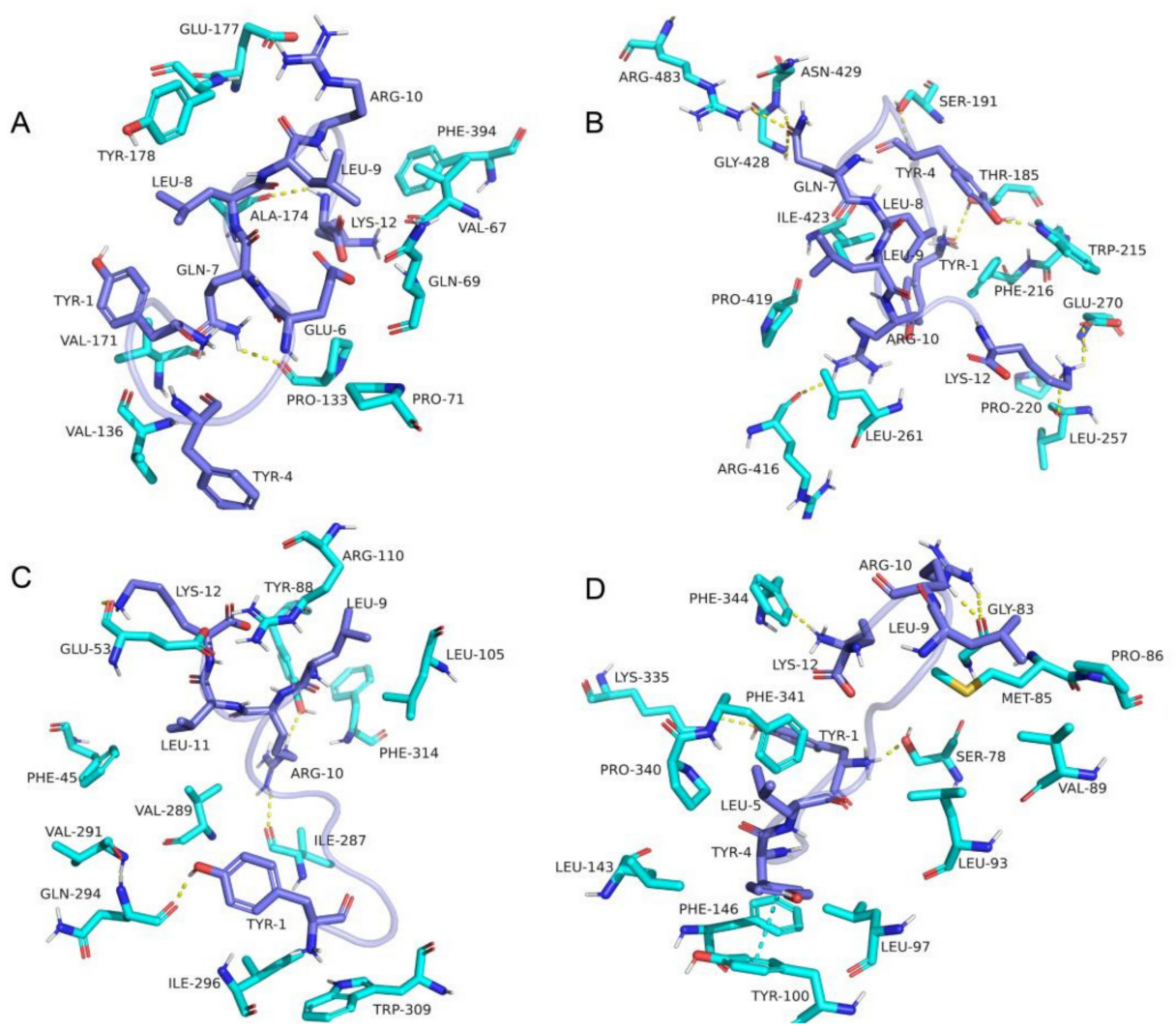

Figure 5. Molecular docking analysis of the binding mode of BCp12. (A) 3-ketoacyl COA thiolase (fadA, Alphafold database). (B) acyl-CoA dehydrogenase (fadE, PDB ID:3DJL). (C) s-(hydroxymethyl) glutathione dehydrogenase (frmA, Alphafold database). (D) acyltransferase (aas,PDB ID:6Q3A). The yellow dotted line indicates hydrogen bonding, and the cyan dotted line indicates pi-pi conjugation.

The scores of the four groups were less than $-5 \mathrm{kcal} / \mathrm{mol}$, indicating that $\mathrm{BCp} 12$ has a strong binding force with the four key enzymes. BCp12 had a strong inhibitory effect on the four key enzymes, possibly inhibiting the fatty acid degradation pathway. 
Table 1. Docking binding energy between BCp12 and target protein.

\begin{tabular}{|c|c|c|c|}
\hline Target Protein & $\begin{array}{l}\text { Docking Score } \\
\text { (kcal/mol) }\end{array}$ & Hydrogen Bond Binding Site & $\begin{array}{c}\text { Hydrophobic Interaction Binding } \\
\text { Site }\end{array}$ \\
\hline 3-ketoacyl-CoA thiolase (fadA) & -6.3 & ala-174,pro-133 & $\begin{array}{l}\text { tyr- } 178, \text { phe-394, val-67, gln- } 69 \text {, } \\
\text { pro- } 133 \text {, pro- } 41, \text { val-136 and val- } 171\end{array}$ \\
\hline acyl-CoA dehydrogenase (fadE) & -6.9 & $\begin{array}{l}\text { arg- } 483 \text {, asn- } 429, \text { gly-428, } \\
\text { ser-191, thr-185, Glu-270, } \\
\text { pro-220 and arg-416 }\end{array}$ & $\begin{array}{l}\text { ille-423, pro-419, leu-261 and } \\
\text { phe-216 }\end{array}$ \\
\hline $\begin{array}{l}\text { S-(hydroxymethyl)glutathione } \\
\text { dehydrogenase (frmA) }\end{array}$ & -7 & tyr- 88 , ile-287 and gln-294 & $\begin{array}{l}\text { phe-45, val-291, val-289, ile-296, } \\
\text { trp-309, phe-314, leu-105 and ile-287 }\end{array}$ \\
\hline Acyltransferase (aas) & -7.5 & $\begin{array}{l}\text { phe-344, arg- } 10, \text { ser-78 and } \\
\text { phe-341 }\end{array}$ & $\begin{array}{l}\text { met-85, pro-86, VAL-89, Leu-93, } \\
\text { leu-97, phe-146, leu-143, pro-340 } \\
\text { and phe-341 }\end{array}$ \\
\hline
\end{tabular}

\subsection{In Vitro Interaction between $B C p 12$ and $D N A$}

Electrophoretic mobility of DNA coupled with BCp12 was measured to determine whether BCp12 targets DNA. BCp12 could bind to E. coli DNA in the untreated control to a certain extent, thus forming a bright electrophoretic product (Figure 6). A certain amount of DNA interacted with BCp12 at $1-2 \mathrm{mg} / \mathrm{mL} \mathrm{BCp} 12$, forming a less visible electrophoretic product. Xie [52] found that antimicrobial peptides bind to the surface of DNA at low concentrations, thus blocking DNA migration. In contrast, high concentrations of antimicrobial peptides bind to the surface of the DNA double helix through electrostatic force, thus competing and hindering the binding of ethidium bromide with DNA, hence forming no electrophoresis product. Yonezawa [53] reported that tachyplesin I exerts its antimicrobial activity by binding to DNA, thus inhibiting the synthesis of macromolecules. Moreover, the antimicrobial activity of HMGN2 against $E$. coli might be associated with its ability to bind to DNA [54]. Therefore, BCp12 can bind to DNA in vitro and affect gene transcription and translation, consistent with expression changes of cell membrane-related protein findings.

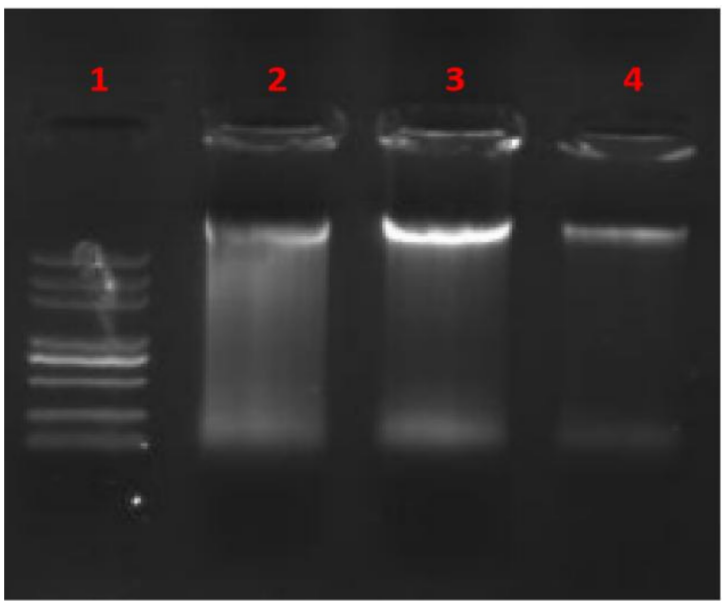

Figure 6. Gel retardation assay of BCp12. (1) Marker; (2-4) BCp12 at concentrations 1, 0, $2 \mathrm{mg} / \mathrm{mL}$, respectively.

\section{Conclusions}

$\mathrm{BCp} 12$ treatment damaged the cell envelope integrity of $E$. coli, and some cell contents leaked to form a cavity, making the FITC-BCp12 and PI enter the cells and emit green and red fluorescence signals at the edges. Furthermore, the iTRAQ proteome analysis showed that BCp12 treatment significantly influenced cellular, metabolic, biological adhesion, and multi-organism processes. Importantly, $\mathrm{BCp} 12$ could bind to genes encoding four key enzymes involved in the fatty acid degradation pathway through hydrogen bonding and 
hydrophobic interactions, thus significantly inhibiting their activities, which disrupts the synthesis of cell membranes. Overall, these results indicate that BCp12 can inhibit the growth of E. coli, cause metabolic disorders, and destroy the structure of cell membranes. Understanding the bactericidal mechanism of BCp12 can guide its future development and utilization as an effective antibacterial agent.

Author Contributions: K.Y.: conceptualization, investigation, writing-original draft, project administration; Y.S.: conceptualization, supervision, writing — review \& editing (K.Y. and Y.S. contributed equally to this work); Y.L.: validation; G.W.: investigation; Q.Z.: software; A.H.: conceptualization, supervision, writing - review and editing, project administration. All authors have read and agreed to the published version of the manuscript.

Funding: This work was financially supported by the Key Yunnan Agricultural Foundation Project (Grant No. 2018FG001-011) and the Scientific Research Program Funded by the Yunnan Provincial Education Department (2020Y190).

Institutional Review Board Statement: Not applicable.

Informed Consent Statement: Not applicable.

Data Availability Statement: The data presented in this study are available within the article.

Conflicts of Interest: The authors declare that they have no known competing financial interest or personal relationship that could have appeared to influence the work reported in this paper.

\section{References}

1. Yi, L.; Luo, L.; Chen, J.; Sun, H.; Lv, X. Cell wall and DNA damage of Staphylococcus aureus by bacteriocin BM1157. LWT Food Sci. Technol. 2020, 134, 109842. [CrossRef]

2. Ruegg, P.L. A 100-Year Review: Mastitis detection, management, and prevention. J. Dairy Sci. 2017, 100, 10381-10397. [CrossRef] [PubMed]

3. Cao, T.H.; Liu, G.H. Analysis on detection results of foodborne pathogens in meat and meat products in Tonghua city from 2014 to 2018. Chin. J. Public Heath Eng. 2020, 1, 39-41.

4. Guo, Y.D.; Fan, L.; Tang, X.S. Investigation on microbial contamination status of takeaway catering in Yunnan province in 2018. J. Food Saf. Qual. 2019, 10, 6.

5. Zang, Y.; Jiang, J.; Fu, Z.Q. Surveillance of microbial contamination in processing of cooked-meat products in Nanchong from 2015 to 2017. J. Prev. Med. Inf. 2018, 34, 4.

6. Mazdeh, F.Z.; Aftabdari, F.E.; Moradi-Khatoonabadi, Z.; Shaneshin, M.; Torabi, P.; Ardekani, M.S. Sodium benzoate and potassium sorbate preservatives in iranian doogh. Food Addit. Contam. Part B 2014, 7, 115119.

7. Kashani, H.H.; Nikzad, H.; Mobaseri, S.; Hoseini, E.S. Synergism Effect of Nisin Peptide in Reducing Chemical Preservatives in Food Industry. Life Sci. J. 2012, 9, 496-501.

8. Vaisocherová-Lísalová, H.; Víšová, I.; Ermini, M.L.; Špringer, T.; Chadtová Song, X.; Mrázek, J.; Lamačová, J.; Lynn, N.S.; Šedivák, P.; Homola, J. Low-fouling surface plasmon resonance biosensor for multi-step detection of foodborne bacterial pathogens in complex food samples. Biosens. Bioelectron. 2016, 80, 84-90. [CrossRef]

9. Hao, G.; Hui, H.; Ma, D.Y. Studies on the inhibition of the synthesis of E. coli macromolecules by antimicrobial peptide BuforinII derivatives. Microbiol. Bull. 2013, 40, 9.

10. Pu, C.; Tang, W. Affinity and selectivity of anchovy antibacterial peptide for Staphylococcus aureus cell membrane lipid and its application in whole milk. Food Control 2017, 72, 153-163. [CrossRef]

11. Ciumac, D.; Gong, H.; Hu, X.; Lu, J.R. Membrane targeting cationic antimicrobial peptides. J. Colloid Interface Sci. 2019, 537, 163-185. [CrossRef] [PubMed]

12. Moraes, L.; Vieira, R.; Nakaie, C.R.; Miranda, A. Conformational and functional studies of gomesin analogues by cd, epr and fluorescence spectroscopies. BBA Biomembr. 2007, 1768, 52-58. [CrossRef] [PubMed]

13. Wood, S.J.; Park, Y.A.; Kanneganti, N.P.; Mukkisa, H.R.; Crisman, L.L.; Davis, S.E. Modified cysteine-deleted tachyplesin (cdt) analogs as linear antimicrobial peptides: Influence of chain length, positive charge, and hydrophobicity on antimicrobial and hemolytic activity. Int. J. Pept. Res. Ther. 2014, 20, 519-530. [CrossRef]

14. Turk, M.; Grimalt, J.; Gunde-Cimerman, N.; Plemenita, A. Salt-induced changes in lipid composition and membrane fluidity of halophilic yeast-like melanized fungi. Extremophiles 2004, 8, 53-61. [CrossRef]

15. Li, Y.Q.; Han, Q.; Feng, J.L.; Tian, W.L.; Mo, H.Z. Antibacterial characteristics and mechanisms of $\epsilon$-poly-lysine against Escherichia coli and Staphylococcus aureus. Food Control 2016, 59, 282-289.

16. Tan, Z.; Shi, Y.; Xing, B.; Hou, Y.; Cui, J.; Jia, S. The antimicrobial effects and mechanism of $\varepsilon$-poly-lysine against Staphylococcus aureus. Bioresour. Bioprocess. 2019, 6, 11. [CrossRef] 
17. Scocchi, M.; Mardirossian, M.; Runti, G. Non-membrane permeabilizing modes of action of antimicrobial peptides on bacteria. Curr. Top. Med. Chem. 2016, 16, 70-88. [CrossRef]

18. Maldonado-Barragan, A.; Cardenas, N.; Martinez, B.; Ruiz-Barba, J.L.; Garvicin, A. A novel class IId bacteriocin from Lactococcus garvieae that inhibits septum formation in L. garvieae strains. Appl. Environ. Microbiol. 2013, 79, 4336-4346. [CrossRef]

19. Duan, F.; Li, X.; Cai, S.; Xin, G.; Liu, X.; Huang, W. Haloemodin as novel antibacterial agent inhibiting DNA gyrase and bacterial topoisomerase i. J. Med. Chem. 2014, 57, 3707-3714. [CrossRef]

20. Mardirossian, M.; Perebaskine, N.; Benincasa, M.; Gambato, S.; Wilson, D.N. The Dolphin Proline-Rich Antimicrobial Peptide Tur1A Inhibits Protein Synthesis by Targeting the Bacterial Ribosome. Cell Chem. Biol. 2018, 25, 530-539. [CrossRef]

21. Lü, A.; Hu, X.; Wang, Y.; Shen, X.; Li, X.; Zhu, A.; Tian, J.; Ming, Q.; Feng, Z. Itraq analysis of gill proteins from the zebrafish (Danio rerio) infected with Aeromonas hydrophila. Fish Shellfish Immun. 2014, 36, 229-239. [CrossRef]

22. Miao, J.; Chen, F.; Duan, S.; Gao, X.; Chen, Y. Itraq-based quantitative proteomic analysis of the antimicrobial mechanism of peptide F1 against Escherichia coli. J. Agric. Food Chem. 2015, 63, 7190-7197. [CrossRef] [PubMed]

23. Zhao, Q.; Li, S.; Chen, C.H.; Huang, A. Preparation of antimicrobial peptides by hydrolysis of betel nut river buffalo casein with Hypericum perforatum protease. Food Ind. 2020, 41, 5.

24. Zhao, Q.; Shi, Y.; Wang, X.; Huang, A. Characterization of a novel antimicrobial peptide from buffalo casein hydrolysate based on live bacteria adsorption. J. Dairy Sci. 2020, 103, 11116-11128. [CrossRef] [PubMed]

25. Su, M.; Liu, F.; Luo, Z.; Wu, H.; Miao, Y. The antibacterial activity and mechanism of chlorogenic acid against foodborne pathogen Pseudomonas aeruginosa. Foodborne Pathog. Dis. 2019, 16, 823-830. [CrossRef] [PubMed]

26. Wang, Q.; Miao, J.Y.; Feng, K. Antibacterial action of peptide F1 against colistin resistance E. coli shp45 (mcr-1). Food Funct. 2010, 11, 10231-10241. [CrossRef]

27. Shu, J.L.; O’Brien-Simpson, N.M.; Pantarat, N.; Sulistio, A.; Qiao, G. Combating multidrug-resistant gram-negative bacteria with structurally nanoengineered antimicrobial peptide polymers. Nat. Microbiol. 2016, 1, 16162

28. Kang, J.; Jin, W.; Wang, J.; Sun, Y.; Wu, X.; Liu, L. Antibacterial and anti-biofilm activities of peppermint essential oil against Staphylococcus aureus. LWT 2019, 101, 639-645. [CrossRef]

29. Jung, W.K.; Koo, H.C.; Kim, K.W.; Shin, S.; Kim, S.H.; Park, Y.H. Antibacterial activity and mechanism of action of the silver ion in Staphylococcus aureus and Escherichia coli. Appl. Environ. Microbiol. 2008, 74, 2171-2178. [CrossRef]

30. Ma, W.; Zhang, D.; Li, G.; He, G.; Zhang, P. Antibacterial mechanism of daptomycin antibiotic against Staphylococcus aureus based on a quantitative bacterial proteome analysis. J. Proteom. 2017, 150, 242-251. [CrossRef]

31. Bronwen, M.; Randall, B.; Becker, K.G.; Marjan, G.; Stuart, M. Itraq analysis of complex proteome alterations in 3xtgad Alzheimer's mice: Understanding the interface between physiology and disease. PLOS ONE 2008, 7, e2750.

32. Shi, X.; Wang, X.; Cheng, F.; Cao, H.; Liang, H.; Lu, J.; Kong, Q.; Bie, Z. Itraq-based quantitative proteomics analysis of cold stress-induced mechanisms in grafted watermelon seedlings. J. Proteom. 2019, 192, 311-320. [CrossRef] [PubMed]

33. Guo, W.; Zhou, X.; Xu, L.N.; Fu, X.J. Effects of cold storage on Microstructure and metabolites of grass carp meat. Food Sci. 2022, 1, $1-13$.

34. Bandyopadhyay, S.; Lee, M.; Sivaraman, J.; Chatterjee, C. Model membrane interaction and DNA-binding of antimicrobial peptide lasioglossin ii derived from bee venom. Biochem. Biophys. Res. Commun. 2013, 430, 1-6. [CrossRef]

35. Boulos, L.; Prevost, M.; Barbeau, B.; Coallier, J.; Desjardins, R. LIVE/DEAD ${ }^{\circledR}$ BacLight ${ }^{\mathrm{TM}}$ : Application of a new rapid staining method for direct enumeration of viable and total bacteria in drinking water. J. Microbiol. Methods 1999, 37, 77-86. [CrossRef]

36. Shai, Y. Mode of action of membrane active antimicrobial peptides. Biopolymers 2002, 66, 236-248. [CrossRef]

37. Chen, F.L. The Mechanism of Antibacterial Peptide Produced by Lactobacillus paracasei FX-6 against Staphylococcus aureus and Its Application. Master's Thesis, South China Agricultural University, Guangzhou, China, 2016.

38. Xiao, H.Q.; Li, Y.Z.; Lin, Q.L. Advances on multiple-targets action mechanism of antimicrobial peptides. J. Food Sci. Biotechnol. 2012, 21, 3-5.

39. Brogden, K. Antimicrobial peptides: Pore formers or metabolic inhibitors in bacterial. Nat. Rev. Microbiol. 2005, 3, 238-250. [CrossRef]

40. Chang, L.; Wang, J.; Tong, C.; Liu, X. Antibacterial mechanism of polyacrylonitrile fiber with organophosphorus groups against Escherichia coli. Fibers Polym. 2016, 17, 721-728. [CrossRef]

41. Yang, S.; Li, J.; Aweya, J.; Yuan, Z.; Liu, G.M. Antimicrobial mechanism of Larimichthys crocea whey acidic protein-derived peptide (lcwap) against Staphylococcus aureus and its application in milk. Int. J. Food Microbiol. 2020, 335, 108891. [CrossRef]

42. Maya, F.; Ganesan, N. Synergistic effect of low power ultrasonication on antimicrobial activity of cecropin p1 against E. coli in food systems. LWT 2018, 96, 175-181.

43. Lu, X.; Vora, H.; Khosla, C. Overproduction of free fatty acids in E. coli: Implications for biodiesel production. Metab. Eng. 2008, 10, 333-339. [CrossRef]

44. Zhou, Y.S. The Effect of Reducing Power Producing Enzyme on E. coli Fatty Acid Synthesis. Ph.D. Thesis, Jiangnan University, Wuxi, China, 2013.

45. Campbell, J.W.; Cronan, J.E. The enigmatic Escherichia coli fade gene is yafH. J. Bacteriol. 2002, 184, 3759. [CrossRef] [PubMed]

46. Steen, E.J.; Kang, Y.; Bokinsky, G.; Hu, Z.; Schirmer, A.; McClure, A. Microbial production of fatty-acid-derived fuels and chemicals from plant biomass. Nature 2010, 463, 559-562. [CrossRef] 
47. Luo, L.; Yi, L.; Chen, J.; Liu, B.; Xin, L. Antibacterial mechanisms of bacteriocin BM1157 against Escherichia coli and Cronobacter sakazakii. Food Control. 2020, 123, 107730. [CrossRef]

48. Patel, H.; Brunton, V.G. Loss of frma leads to increased cell-cell adhesion and impaired multi-cellular development of dictyostelium cells. Cell. Mol. Life Sci. 2009, 66, 145-155. [CrossRef] [PubMed]

49. Mihaly, V.; Stephen, A.; Mandar, D.; Sreenath, N.; Cindy, N.; Galabina, Y. Alphafold protein structure database: Massively expanding the structural coverage of protein-sequence space with high-accuracy models. Nucleic Acids Res. 2021, 50, D439-D444.

50. Callaway, E. DeepMind's AI predicts structures for a vast trove of proteins. Nature 2021, 595, 635. [CrossRef]

51. Han, Q.; Liu, F.; Wen, X.; Ni, Y. Kinetic, spectroscopic, and molecular docking studies on the inhibition of membrane-bound polyphenol oxidase from granny smith apples (malus domestica borkh). Food Chem. 2020, 338, 127928. [CrossRef]

52. Xie, H.; Yang, X.; Ke, C.; Xu, H.; Guo, Y. The molecular mechanism of chemical synthesis of antimicrobial peptides in inhibiting pathogenic Escherichia coli F41. Mod. Food Sci. Technol. 2016, 1, 44-51.

53. Yonezawa, A.; Kuwahara, J.; Fujii, N.; Sugiura, Y. Binding of tachyplesin i to DNA revealed by footprinting analysis: Significant contribution of secondary structure to DNA binding and implication for biological action. Biochemistry 1992, 31, 2998-3004. [CrossRef] [PubMed]

54. Li, H.; Shen, X.F.; Zhou, X.E. Antibacterial mechanism of high-mobility group nucleosomal-binding domain 2 on the Gramnegative bacteria Escherichia coli. J. Zhejiang Univ. Sci. B 2017, 18, 410-420. [CrossRef] [PubMed] 